\title{
PHARMACOGNOSTICAL AND PRELIMINARY PHYTOCHEMICAL SCREENING OF AAVAARAI VIDHAI CHOORANAM
}

\author{
UMA KS ${ }^{1 *}$, PARTHIBAN ${ }^{2}$, KALPANA $S^{3}$ \\ ${ }^{1}$ Department of Siddha, The Tamil Nadu Dr. M. G. R. Medical University, Chennai - 600 032, Tamil Nadu, India. ${ }^{2}$ Department of Indian \\ Medicine and Homoeopathy, Arumbakkam, Chennai - 600 106, Tamil Nadu, India. ${ }^{3}$ Department of Epidemiology, The Tamil Nadu \\ Dr. M. G. R. Medical University, Chennai - 600 032, Tamil Nadu, India. Email: uma.ks@tnmgrmu.ac.in
}

Received: 27 April 2017, Revised and Accepted: 15 June 2017

ABSTRACT

Objective: To study the organoleptic characters, physio chemical properties and preliminary phytochemicals screening of Siddha formulations Aavaarai Vidhai Chooranam (AVC).

Methods: The study drug, AVC was prepared as per procedure given in the text Neerizhivu maruthuvam. Organoleptic characteristics were assessed by appearance, colour, taste and odour. The physiochemical property of trial drug was screened for moisture content, total ash value, acid insoluble ash, water soluble extractive value, alcohol soluble extractive value, $\mathrm{pH}$, reducing sugar, total sugar, total solid content and fat content. Preliminary Phytochemical evaluation of AVC was carried out by the standard procedure. The drug was screened for alkaloids, amino acids \& proteins, anthraxquinone, carbohydrate, flavonoids, glycosides, phenols quinones, resins, saponins, steroids tanins, terpenoids and sugar. For which the aqueous extraction of the trial drug was taken by dissolving the $5 \mathrm{~g}$ of sample with $50 \mathrm{ml}$ of distilled water and heated over water bath at $60^{\circ} \mathrm{C}$. Then extract was filtered and used the filtrates for testing.

Results: The trial drug, AVC shown organoleptic characters as per literature evidence, physiochemical properties as moisture content, total ash value, acid insoluble ash, water soluble extractive value, alcohol soluble extractive value, $\mathrm{pH}$, reducing sugar, total sugar, total solid content and fat content were found within normal limits, preliminary phytochemical test showed the presence of flavonoids, tannins, steroids, terpenoids, alkaloids, carbohydrate, proteins, phenols and sugar.

Conclusion: Organoleptic characters, physio chemical properties and preliminary photochemica shows that the drug has the quality and potency to treat against diabetes mellitus. To confirm this activity, further research should be done to assess the safety and efficacy of the drug AVC.

Keywords: Cassia auriculata, Siddha formulations, Organoleptic characters, Physiochemical properties, Preliminary phytochemical analysis, Aavaarai vidhai chooranam.

(c) 2017 The Authors. Published by Innovare Academic Sciences Pvt Ltd. This is an open access article under the CC BY license (http://creativecommons. org/licenses/by/4. 0/) DOI: http://dx.doi.org/10.22159/ajpcr.2017.v10i10.19422

\section{INTRODUCTION}

Medicinal plants are richest bioresources of drugs of traditional systems of medicine, modern medicines, nutraceuticals, food supplements, folk medicines, pharmaceuticals intermediates, and chemical entities for synthetic drugs [1].

India is having a rich heritage value of traditional medicine constituting with its different components such as Siddha, Ayurveda, and Unani, where herbal drugs constitute a major part. The development of these traditional systems of medicines with the perspectives of safety, efficacy, and quality will help not only to preserve the traditional heritage but also to rationalize the use of herbal products in the health sector.

Since there is no side effects proved for siddha medicine by the scientific evidence now-a-days world's focus turns to the herbal medicine. Many herbal formulations have been used as anti-diabetic. In particularly Siddha system, treating the diseases is mainly using herbs. Recent overwhelming attention to plant products and alternative medicine has encouraged plant chemists, pharmacologists, biochemists, and molecular biologists to combine their efforts in a search for natural agents that can control diabetes mellitus and its complications [2].

In siddha system of medicine, according to the siddha classical text Neerizhivu maruthuvam diabetes mellitus can be managed by the drug Aavaraai Vidhai Chooranam (AVC) but at present which is not in practice by all the siddha physicians because of there was no proper proved scientific evidence. Instead of AVC, two or three Siddha formulations is used to manage diabetes mellitus by Madhumega chooranam, Navalkottai chooranam, Seenthil sukku kudineeretc. Since there is no study available on the trail drug AVC, this study aims to standardize the same drug for future evidence based practice.

Avarai churnam is selected from the Siddha text. The study drug, AVC (Avaarai Vidhai Chooranam) is a combination of drugs, i.e., Cassia auriculata, Curcuma longa, Strychnos potatorum, Coscinium fenestratum, and Acacia nilotica.

C. auriculata belongs to Fabaceae family; it is a much branched shrub with smooth cinnamon brown bark and closely pubescent bracelets. The fruit is a short legume. It occurs in the dry regions of India and Sri Lanka. C. auriculata possess benzoic acid, resorcinol, and capric acid ethyl ester. Glycine, dodecanoic acid, linoleic acid, oleic acid, grape seed oil, stearic acid, palmitic acid, dl- $\alpha$-tocopherol, stigmasta, dimethoxyacetophenone, fatty acid, and fatty acid ester [3]. C. auriculata flower extract contains flavonoid and phenols in a significant amount [4]. The flowers, leaves, and seeds methanolic extracts of $C$. auriculata have significant antioxidant activity [5]. Therapeutic effect of $C$. auriculata is diabetes mellitus [6], dysentery, hepatoprotective [7], rheumatism, fever, excessive thirst, eye diseases, chronic purulent conjunctivitis, gout, and gonorrhea [8].

C. fenestratum is a robust woody climbing shrub with bright yellow sap, yellowish, densely hairy when young, leaves leathery, shining, and 
smooth on upper surface, slightly hairy on lower surface, roundish, with tapering tip, and main nerves 5-7. Flowers minute, in small heads. $C$. longa. Linn. is a rhizomatous herbaceous perennial plant of the ginger family Zingiberaceae. It reaches up to $1 \mathrm{~m}$ tall. Highly branched, yellow to orange cylindrical aromatic rhizomes are found. Curcuma contains curcuminoids, curcumin, demethoxy curcumin, bisdemethoxycurcumin, and dihydrocurcumin. Therapeutic effect of $C$. longa is diabetes mellitus, cancer, arthritis, inflammation, respiratory disorders, gastrointestinal disorder, and allergy, bacterial, and viral and fungal infection [9].

C. fenestratum stem bark has hepatorenal protective effect in streptozotocin-induced diabetic rats [10]. Curcumin appears to be beneficial in preventing diabetes-induced oxidative stress in rats [11]. Acetone extract of C. longa contained 15 phytochemicals, methanol extract contained 16 phytochemicals, ethanol extract had 13 phytochemicals, and chloroform extract had 12 phytochemicals [12]. 18 chemical compounds in the ethanolic extract of the seed of C. auriculata [3]. Bioflavonoids are nowadays regarded as promising and significantly alternative natural substance to enrich the current therapy option against diabetes [13].

There is no data available regarding the standardization of AVC. It was planned to standardize Siddha formulation AVC to develop evidence-based Siddha medicine. The objective of the study was to identify organoleptic characters, physiochemical properties, and the preliminary phytochemical compound present in AVC.

\section{METHODS}

\section{Preparation of the study drug}

The study drug was prepared as per good manufacturing practice Guidelines of the Drugs and Cosmetics Act 1947. The study drug was prepared according to the method mentioned in the Siddha text [14] under the direct supervision at Gunapadam Laboratory of The Tamil Nadu Dr. M. G. R. Medical University, Chennai.

All the drugs were purchased from authenticated drug dealer, and the same was authenticated by the Siddha Central Research Institute, Chennai. All the drugs were purified as per Siddha text [15] and powdered into a fine powder and stored for the further utilization.

\section{Organoleptic characters of AVC}

\section{Macroscopic examination}

The study drug was characterized by color, odor, taste, and texture using traditional and standard techniques $[16,17]$.

\section{Physiochemical analysis}

Physicochemical evaluation of the study drug was screened for moisture content, total ash value, acid-insoluble ash, water-soluble extractive value, acid soluble extractive value, $\mathrm{pH}$, reducing sugar, total sugar, total solid content, and fat content by standard procedure [18].

Physiochemical analysis of AVC was performed at The Madras Industrial co-operative Analytical Laboratory Ltd. (MICAL) Chennai.

\section{Determination of moisture content (loss on drying)}

Determination of moisture content (loss on drying) was studied to rule out an excess of moisture/water in the study drug. If the excess water content is present in the plant materials, it may be lead to contaminate with microbial growth, such as the presence of bacteria and fungi which affect the quality of prepared drug.

\section{For moisture content estimation}

About $10 \mathrm{~g}$ of AVC was accurately weighed in a tarred evaporating dish. Then, it was dried at $105^{\circ} \mathrm{C}$ for $5 \mathrm{hrs}$ and weighed. The procedure was repeated at hourly intervals till consistent weight was achieved. It was calculated using the following formula:
Percentage of loss on drying at $105^{\circ} \mathrm{C}=\frac{\text { Loss } \in \text { Weight of the sample }}{\text { Weight of thesamplestaken }} \times 100$

\section{Determination of total ash values}

The ash remaining following ignition of AVC is determined by three different methods which measure total ash, acid-insoluble ash, and water-soluble ash.

The total ash method was designed to measure the total amount of material remaining after ignition. This includes both "physiological ash," which was derived from the plant tissue itself, and "nonphysiological" ash, which was the residue of the extraneous matter (e.g., sand and soil) adhering to the plant surface.

\section{For estimation of total ash}

About $4 \mathrm{~g}$ of AVC weighed, placed evenly in a previously ignited and tarred silica dish. Ignited in a muffle furnace at $600^{\circ} \mathrm{C}$ until it turned white in color. It indicated the absence of carbon.

$$
\text { Percentage of total ash }=\frac{\text { Weight of the ash }}{\text { Weight of the sample taken }} \times 100
$$

\section{Determination of acid-insoluble ash}

Acid-insoluble ash is the residue obtained after boiling the total ash with dilute hydrochloric acid and igniting the remaining insoluble matter. This measures the amount of silica present, especially as sand and siliceous earth.

\section{For estimation of acid-insoluble ash}

Added to the ash $15-25 \mathrm{ml}$ of the hydrochloric acid and boiled for 10 minutes, covering the dish with a watch glass to prevent sputtering. It was allowed to cool; then the content was filtered through the ash less filter paper. The filter paper was washed in hot water until the paper was free from hydrochloric acid, as tested by silver nitrate solution and returned it to the dish. Then, the paper was evaporated carefully on the water bath and ignited in the muffle furnace at $550^{\circ} \mathrm{C} \pm 25^{\circ} \mathrm{C}$ for $1 \mathrm{hr}$. The dish was allowed to cool in the desiccators and weighted.

$$
\text { Percentage of acid insoluble ash }=\frac{\begin{array}{c}
\text { Weight of theacidin } \\
\text { solubleresidueweight }
\end{array}}{\text { Weight of thesamplestaken }} \times 100
$$

\section{Determination of water-soluble extractive value}

About $4 \mathrm{~g}$ of the AVC was taken in a glass stopper flask. Added $100 \mathrm{ml}$ of distilled water and shaken at approximately 30 minutes intervals for 6 hrs and allowed to stand for $18 \mathrm{hrs}$. Filtered rapidly taking care not to lose any solvent and pipette out $25 \mathrm{ml}$ of the filtrate in a pre-weighed $100 \mathrm{ml}$ beaker and evaporate to dryness on a water bath and kept it in an air oven at $105^{\circ} \mathrm{C}$ for $6 \mathrm{hrs}$, cooled in a desiccator and weighed. Repeat the experiment twice and take the average value.

Percentage of water soluble extractive $=\frac{\text { Weight of extract } 100}{25 \times \text { weight of thesample taken }} \times 100$

\section{Determination of alcohol soluble extractive value}

About $4 \mathrm{~g}$ of the AVC was taken in a glass stoppered flask. Added $100 \mathrm{ml}$ of distilled alcohol (approximately $95 \%$ ) and shaken at approximately 30 -minute intervals for $6 \mathrm{hrs}$ and allowed to stand for $18 \mathrm{hrs}$. Filtered rapidly taking care not to lose any solvent and pipette out $25 \mathrm{ml}$ of the filtrate in a pre-weighed $100 \mathrm{ml}$ beaker and evaporate to dryness on a water bath and kept it in an air oven at $105^{\circ} \mathrm{C}$ for $6 \mathrm{hrs}$, cooled in a desiccator and weighed. Repeat the experiment twice and take the average value.

Percentage of alcohol soluble extractive $=\frac{\text { Weight of extract } 100}{25 \times \text { weight of thesampletaken }} \times 100$ 


\section{Determination of $\mathbf{p H}$ Value}

\section{Procedure for preparation of buffer solutions}

Standard buffer solution $\mathrm{pH}$ 4: One tablet of pH 4 dissolved in $100 \mathrm{ml}$ of distilled water. Standard buffer solution $\mathrm{pH}$ 7: One tablet of $\mathrm{pH} 7$ dissolved in $100 \mathrm{ml}$ of distilled water. Standard buffer solution $\mathrm{pH}$ 9.2: One tablet of pH 9.2 dissolved in $100 \mathrm{ml}$ of distilled water for liquid use the sample as such.

About $10 \mathrm{~g}$ of AVC was taken and added $100 \mathrm{ml}$ of distilled water stirred well and filtered. The filtrate was used for the experiment. Switched on the instrument given 30 minutes time for warming $\mathrm{pH}$ meter. Introduced the $\mathrm{pH} 4$ solution first adjust the $\mathrm{pH}$ meter to 4 using the knob, 4.00 for room temperature $20^{\circ} \mathrm{C}, 4.01$ for room temperature $25^{\circ} \mathrm{C}$, and 4.02 for room temperature $30^{\circ} \mathrm{C}$. Then, introduced the $\mathrm{pH} 7$ solution and adjust the $\mathrm{pH}$ meter to 7 using the knob. Then, introduced the $\mathrm{pH} 9.2$ solution and checked the $\mathrm{pH}$ reading without adjusting the knob. Then, introduced the sample solution and noted the reading. The test was repeated 4 times, and the average reading was recorded as a result.

\section{Determination of total solids}

\section{Procedure}

Weigh $4 \mathrm{~g}$ of sample in a pre-weighed beaker and evaporate at as low temperature as possible until the solvent is removed and heat on a water bath. Transfer it to an oven and dry it to constant weight at $105^{\circ} \mathrm{C}$. Repeat the experiment twice and take the average value.

$$
\text { Percentage of total solids }=\frac{\text { Weight of theresidue }}{\text { Weight of thesampletaken }} \times 100
$$

\section{Determination of reducing sugar content}

Determination of reducing sugar

Taken the sugar solution in a $50 \mathrm{ml}$ burette.

\section{Preliminary titration}

Pipette $10 \mathrm{ml}$ of Fehling's solution into a $250 \mathrm{~m} 1$ conical flask, and add from the burette, $15 \mathrm{ml}$ of the sugar solution. Boil the liquid on asbestoscovered gauze and add further quantities of the sugar solution $(1 \mathrm{ml}$ at a time) at 10 to 15 -second intervals to the boiling liquid until the blue color is nearly discharged. Then add 3-5 drops of aqueous methylene blue solution $(1 \%)$ and continue the titration until the indicator is completely decolorized.

\section{Accurate titration}

Repeated the titration, before heating, added almost all of the sugar solution required to effect reduction of copper. Boiled gently for 2 minutes, added 3-5 drops of methylene blue indicator and completed the titration within a total boiling time of 3 minutes. At the end point, all the blue color should be discharged, and the liquid should be red. The proportions of various sugars, equivalent to $10 \mathrm{ml}$ of Fehling's solution are given in the table.

\section{Determination of total sugar content}

About $20 \mathrm{ml}$ of reducing sugar was taken and added $10 \mathrm{ml}$ of concentrated hydrochloric acid and kept it aside overnight. Neutralize with approximately IM. Sodium hydroxide and makeup to $100 \mathrm{ml}$ in a volumetric flask. Determine the total sugar content by the titrimetric method described above. Repeat the experiment twice and take the average value.

$$
\begin{gathered}
\text { Mg of sugar in } 100 \mathrm{ml}=\frac{\text { Total reducing sugar }}{\text { Titre }} \times 100 \\
\text { Reducing sugar } \%=\frac{\text { Ether extract }}{1000 \times 100 \times 10} \times 100
\end{gathered}
$$

\section{Determination of Fat content}

\section{Procedure}

Weight $4 \mathrm{~g}$ of the sample in a thimble and place it in an Soxhlet fitted with a condenser. Take $100 \mathrm{ml}$ of petroleum ether in a RB flask and boil or $4 \mathrm{hrs}$. Take the extract in a pre-weighted conical flask and evaporate petroleum ether on water bath. Remove traces of petroleum ether in the vacuum pump. Take the weight of fat to constant weight.

$$
\text { Percentage of fat content }=\frac{\text { Weight of petroleum ether extract }}{\text { Weight of thesampletaken }} \times 100
$$

\section{Determination of preliminary phytochemicals}

Preliminary phytochemical tests were performed on AVC $[1,19]$.

\section{Preparation of extract of study drug}

About $5 \mathrm{~g}$ was taken in a cylindrical beaker, and $50 \mathrm{ml}$ of distilled water was added to it, shaken well and heated for 3 minutes in a water bath. The solution then filtered with the help of Whatman no.1 filter paper. The filtrate was used for the following preliminary phytochemical analysis and identified the constituents.

\section{Determination of alkaloids}

Mayer's test

AVC extract $2 \mathrm{ml}$ was treated with $2 \mathrm{ml}$ of diluted hydrochloric acid; $1 \mathrm{ml}$ of Mayer's reagent was added. Formation of white precipitate indicates the presence of alkaloids.

\section{Wagner's test}

About $2 \mathrm{ml}$ of AVC extract was treated with $2 \mathrm{ml}$ of diluted hydrochloric acid; 3-5 drops of Wagner's reagent (1.27 $\mathrm{g}$ of iodine and $2 \mathrm{~g}$ of potassium iodide in $100 \mathrm{ml}$ of water) and observed for the reddish brown precipitate that confirms the presence of alkaloids.

\section{Dragendroff's test}

About $2 \mathrm{ml} \mathrm{AVC}$ extract was treated $2 \mathrm{ml}$ of diluted hydrochloric acid; a few drops of acetic acid and added $1 \mathrm{ml}$ of Dragendroff's reagent (solution of potassium bismuth iodide) and shaken well. Formation of orange-red precipitate confirms the presence of alkaloids.

Test for amino acids and proteins $(1 \%$ ninhydrin solution in acetone)

About $2 \mathrm{ml}$ of AVC extract was treated with 2-5 drops of ninhydrin solution placed in a boiling water bath for 1-2 minutes and observed for the formation of purple color indicates the presence of amino acids and proteins.

\section{Test for anthraquinones}

Borntrager's test

The AVC extract was macerated with ether and after filtration; aqueous ammonia (or) caustic soda was added. Pink, red (or) violet color in the aqueous layer after shaking indicates the presence of anthraquinones.

\section{Test for carbohydrates (Molisch's test)}

Few drops of Molisch's reagent were added to $2 \mathrm{ml}$ of AVC extract and added $2 \mathrm{ml}$ of concentrated sulfuric acid along the sides of the test tube; then allowed to stand for 2-3 minutes. Formation of a red or violet color at the interphase of the two layers confirms the presence of carbohydrates.

\section{Test for flavonoids}

Alkaline reagent test

About $2 \mathrm{ml}$ of AVC extract was treated with few drops of $20 \%$ sodium hydroxide solution. Formation of intense yellow color, which becomes colorless on addition of diluted hydrochloric indicates the presence of flavonoids. 
Test for glycosides

The AVC extract was mixed with a little anthrone on a watch glass. One drop of concentrated sulfuric acid was added and made into a paste, warmed gently over a water bath. The presence of glycosides was identified by dark green coloration.

\section{Test for phenols}

To the $2 \mathrm{ml}$ of AVC extract, a few drops of aqueous $5 \%$ ferric chloride solution was added, and formation of blue or black color confirms the presence of phenols.

\section{Test for quinones}

To the $2 \mathrm{ml}$ of AVC extract, sodium hydroxide was added. Blue or red coloration indicates the presents of quinones.

\section{Test for resin}

Few $\mathrm{ml}$ of AVC extract was treated with 5-10 ml of acetic anhydride gently heat and cool. To this added $0.05 \mathrm{ml}$ of sulfuric acid. Bright purplish red color rapidly changed to violet color indicates the presence of resins.

\section{Test for saponins}

$2 \mathrm{ml}$ of AVC extract was added with $6 \mathrm{ml}$ of water in a test tube. The mixture was vigorously shaked and observed for the formation of persistent foam that indicates the presence of saponins.

\section{Test for steroids (Liebermann-Burchard test)}

The AVC extract was dissolved in a few drops of chloroform, acetic anhydride and concentrated sulfuric acid. Then observed for the formation of a dark pink or red color that confirms the presence of steroids.

\section{Test for sugars}

About 2 ml of AVC extract was mixed with Fehling's solution A and B and examined for the appearance of red coloration, indicates the presence of sugars.

\section{Test for tannins (Braymer's test)}

About $2 \mathrm{ml}$ of AVC extract was mixed with $10 \%$ alcoholic ferric chloride solution and observed for formation of blue or greenish color solution indicates the presence of tannins.

\section{Test for terpenoids}

\section{Salkowski's test}

The AVC extract $2 \mathrm{ml}$ was treated with $1 \mathrm{ml}$ of chloroform and 2 drops of concentrated sulfuric acid was added to it. A reddish brown precipitate produced immediately indicated the presence of terpenoids.

\section{RESULTS}

\section{Organoleptic characters}

The organoleptic characters such as color, odor, and taste and texture for the study drug AVC were observed by traditional and standard techniques. And results were tabulated in Table 1.

\section{Physiochemical analysis}

The values of the physiochemical analysis of AVC were given below in Table 2.

\section{Preliminary photochemical analysis}

Preliminary phytochemical tests were performed on AVC. The results of the test showed the presence of flavonoids, tannins, steroids, terpenoids, alkaloids, carbohydrate, proteins, phenols, and sugar. Results were tabulated in Figs. 1-3 and Table 3.

TLC mobile phase for all tests: Toluene:ethyl acetate: chloroform:methanol: formic acid was used in the ratio of $3: 3: 3: 1: 0.2$.
Table 1: Organoleptic characters of AVC

\begin{tabular}{lll}
\hline S. No. & Features & Inference \\
\hline 1 & Color & Brown color powder \\
2 & Odor & Agreeable pleasant odor \\
3 & Taste & Astringent \\
4 & Texture & Very fine powder \\
\hline AVC: Aavaarai vidhai chooranam &
\end{tabular}

Table 2: Physiochemical parameters of AVC

\begin{tabular}{lll}
\hline S. No. & Physiochemical parameters & Values in \% \\
\hline 1 & Moisture content & 6.65 \\
2 & Total ash content & 5.69 \\
3 & Acid-insoluble ash & 1.64 \\
4 & Water-soluble extractive value & 6.20 \\
5 & Alcohol soluble extractive value & 2.18 \\
6 & pH of AVC & 5.86 \\
7 & Total solid content & 5.52 \\
8 & Reducing sugar content & 5.39 \\
9 & Total sugar content & 6.09 \\
10 & Fat content & 2.70 \\
\hline
\end{tabular}

All the values are expressed in percentage. AVC: Aavaarai vidhai chooranam

Table 3: Preliminary phytochemical parameter

\begin{tabular}{lll}
\hline S. No. & Phytochemicals & Inference \\
\hline 1 & Alkaloids & + \\
2 & Amino acids and proteins & + \\
3 & Anthraquinone & - \\
4 & Carbohydrate & + \\
5 & Flavonoids & + \\
6 & Glycosides & - \\
7 & Phenols & - \\
8 & Quinones & - \\
9 & Resins & - \\
10 & Saponins & + \\
11 & Steroids & + \\
12 & Sugars & + \\
13 & Tannins & + \\
14 & Terpenoids & \\
\hline
\end{tabular}

+: Present, -: Absent

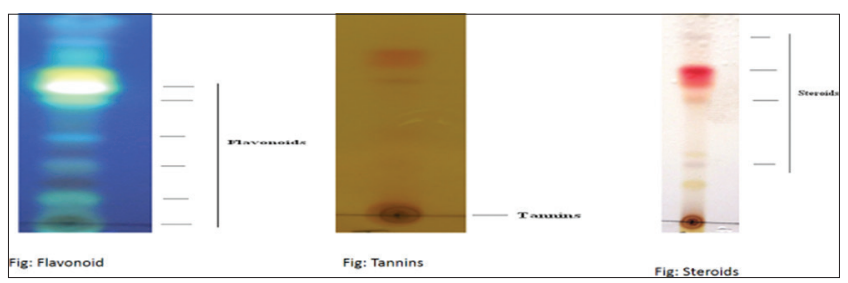

Fig. 1: Preliminary phytochemical analysis

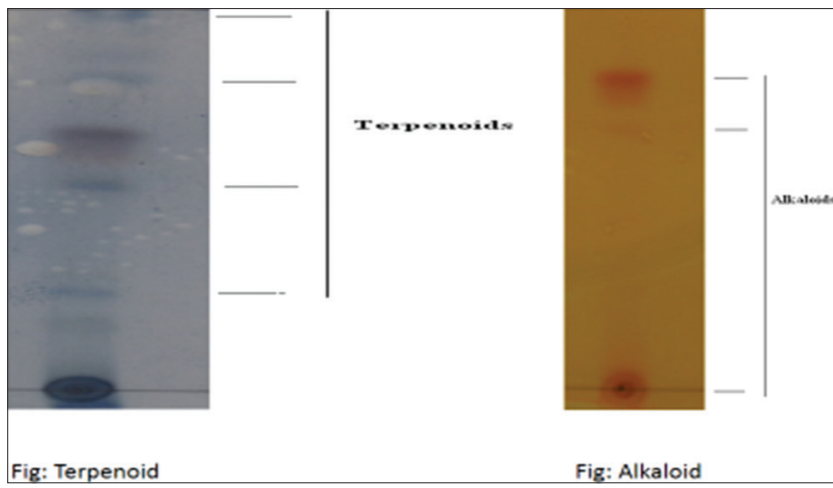

Fig. 2: Preliminary phytochemical analysis 


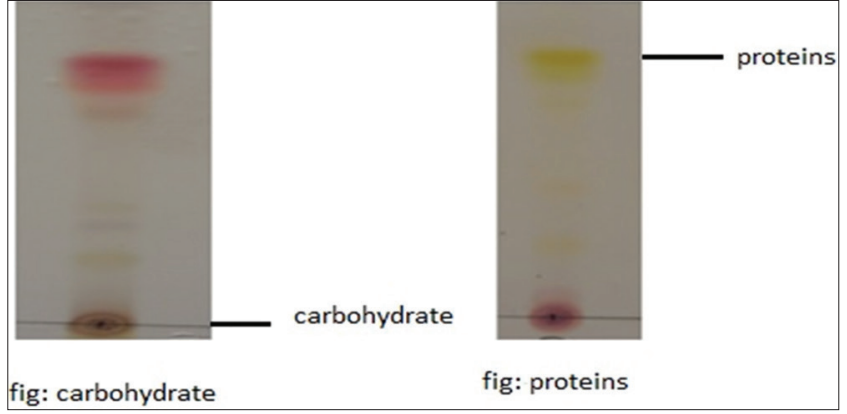

Fig. 3: Preliminary phytochemical analysis

\section{DISCUSSION}

Taste is one of the organoleptic characters; it plays an important role in the treatment of diabetes. AVC has astringent, bitter and pungent taste. Astringent taste has beneficial effects on blood, heals the ulcers, and stops the abnormal discharge from the body. Bitter taste has a purifying and detoxifying effect. It removes the toxins from the blood and other secretions and gives the strength to the nerves. Astringent and bitter tastes decrease the pitha, kapham and obesity and pungent taste neutralizes kapham as per literature [20].

Texture of the drug is another factor that plays a key role in the treatment. When the particle size of the drug is small, the bioavailability of the drug will be more. Since the AVC passes through 80 mesh sizes, it is very fine, and the bioavailability may be more, and thus it influences the efficacy of the drug.

The results of physicochemical analysis of AVC were found within normal limits. Excess moisture content deteriorates the quality of medicine. The moisture level of AVC is $6.65 \%$. Ash value is determined to rule out contamination, adulteration of the raw drugs. It also indicates the presence of inorganic materials and silica. If the ash value is high, it means the drug has high silica content. The ash value of the AVC is $5.69 \%$, and alcohol insoluble ash is $1.64 \%$. This shows that the formulation has a minimal quantity of inorganic material and can be given as internal medicine.

The water-soluble extractive value of AVC is $6.2 \%$ which is greater than the alcohol soluble extractive value $2.18 \%$ indicates that the drug dissolves in water. So it indicates that absorption is high if consume with water. Extract values revealed the solubility and polarity particulars of the metabolites in the AVC.

Extract of aerial parts of Cassia auriculata showed the presence of alkaloids, carbohydrates, fixed oils, tannins, phenols, flavonoids, steroids, saponins, gum and mucilage [21]. In this study the preliminary phytochemical test showed that flavonoids, tannins, steroids, protein, terpenoids, alkaloids, carbohydrate, sugar and Phenols were present in AVC. Data from the literature as well as our results reveal the great potential of plants for the therapeutic treatment. Similar study but with a single drug and analysed by GCMS instead priliminary phytochemical done by Raj et al. showed that phytochemical analysis by GC-MS revealed presence of fatty acid esters, fatty acid amide, terpenoids, diterpene alcohols and phytol as major compound groups in the methanol fractions also they have suggested Compositional variation in quantities, qualities and structural features may influence compounds behavior on GC-MS, as well as bioactivities of their precursor fractions [3]. Study done by Murugan et al. also support this study findings by showing the similar phytochmical properties [22].

Theresults of the preliminaryphytochemical test showed that flavonoids, tannins, steroids, protein, terpenoids, alkaloids, carbohydrate, sugar, and phenols were present in AVC. The phenols and flavonoids possess the antioxidant property and prevent the complications of diabetes. Phytochemicals present in AVC are responsible for efficacy of the drug to control and prevent the diseases indicated for AVC.

\section{CONCLUSION}

The study drug was screened for organoleptic characters, physiochemical properties and preliminary phytochemicals and estimated the quality of the sample. A value of all the parameters of AVC was within the limit and confirmed that quality is good. The study drug possesses flavonoids, phenols which are antioxidant in nature. It is safe to use for the treatment but safety and efficacy study needed to be done before administration to the patients then only it will be evidencebased medicinal practice.

\section{ACKNOWLEDGMENT}

The authors thank the Madras Industrial Co-operative Analytical Laboratory Ltd. Chennai-32 and Asthagiri Herbal Research Foundation Chennai-96 for the providing infrastructure to do this work.

\section{REFERENCES}

1. Tiwari P, Kumar B, Kaur M, Kaur G, Kaur H. Phytochemical screening and extraction-review. Int Pharm Sci 2011;1(1):98-106.

2. Deshpande AD, Harris-Hayes M, Schootman M. Epidemiology of diabetes and diabetes-related complications: Diabetes special issue. Phys Ther 2008;88(11):1254-63.

3. Raj JY, Peter MP, Joy V. Chemical compounds investigation of Cassia auriculata seeds: A potential folklore medicinal plant. Asian J Plant Sci Res 2012;2(2):187-92.

4. Soundharajan SR, Ponnusamy RD. Chemical composition and characterization studies of Cassia auriculata flower extract. Int J Pharm Pharm Sci 2014;6(7):327-30

5. Ashok JP, Harish PH, Prasad WV, Ashok WP. Comparative assessment of antioxidant potential of Cassia auriculata (Linn.) flower, leaf and seed methanolic extracts. Int J Pharm Pharm Sci 2015;7(9):381-5.

6. Joy V, Peter MP, Raj JY, Ramesh. Medicinal values of avaram (Cassia auriculata Linn.): A review. Int J Curr Pharm Res 2012;4(2):1-3.

7. Daisy P, Kani FG. Hypolipidemic and hepatoprotective effects of Cassia auriculata Linn bark extracts on streptozotocin induced diabetics in male Wister albino rats. Asian J Pharm Clin Res 2013;6(2):43-8.

8. Mudaliar KS. Gunapadam Porutpanbu Nool. Part-1, Mooligai Vagupu. $7^{\text {th }}$ ed. Chennai: Department of Indian Medicine and Homeopathy, Government of Tamil Nadu; 2003.

9. Luthra PM, Singh R, Chandra R. Therapeutic uses of Curcuma longa (turmeric). Indian J Clin Biochem 2001;16(2):153-60.

10. Okechukwu PN, Ndyeabura AW, Chiang CN, Akowuah GA. Effect of standardized extract of Cosinium fenestratum stem bark on liver and kidney function parameters in streptozotocin-induced diabetic rats. J Acute Dis 2013;2:201-6.

11. Azza A, El-Masry AA. Potential therapeutic effect of Curcuma longa on streptozotocin induced diabetic rats. Glob Adv Res J Med Med Sci 2012;1(4):91-8.

12. Sawant RS, Godghate AG. Qualitative phytochemical screening of rhizomes of Curcu-ma longa Linn. Int J Environ Sci Technol 2013;2(4):634-41.

13. Brahmachari G. Bio-flavonoids with promising anti-diabetic potentials: A critical survey. Opportunity. Chall Scope Nat Prod Med Chem $2011 ; 187-212$

14. Thiyagarajan R. Yugimuni Vaithya Chinthamani $800.2^{\text {nd }}$ ed. Chennai: Department of Indian Medicine and Homeopathy, Government of Tamil Nadu; 2005.

15. Thiyagarajan R. Gunapaadam Thadhu-Jeeva Vaguppu Part-2 and 3. $2^{\text {nd }}$ ed. Chennai: Department of Indian Medicine and Homeopathy, Government of Tamil Nadu; 2006.

16. Akbar S, Hanif U, Ali J, Ishtiag S. Pharmacognostical studies of stem, roots and leaves of Malva parviflora L. Asian Pac J Trop Biomed 2014;4(5):410-5.

17. Lavanya B, Narayanan N, Maheshwaran A, Suganya S, Sree YS, Aravindan SV, et al. Basic anatomical and pharmacognostical study of Cassia fistula Linn (Caesalpiniaceae). Int J Pharm Biol Sci 2016;6(3):105-20

18. WHO. Quality Control Methods for Medicinal Plant's Materials. Geneva: World Health Organization; 1998. 
19. Ugochukwu SC, Uche IA, Ifeanyi O. Preliminary phytochemical screening of different solvent extracts of stem bark and roots of Dennetia tripetala G. Baker. Asian J Plant Sci Res 2013;3(3):10-3.

20. Venugopal PM. Udal Thathuvam, Unavu Porulin Amsangal. $3^{\text {rd }}$ ed. Chennai: Department of Indian Medicine and Homeopathy, Government of Tamil Nadu; 1993. p. 248-53.
21. Raja DK, Jeganathan NS, Manavalan R. In vitro antimicrobial activity and phytochemical analysis of Cassia auriculata Linn. Int Curr Pharm J 2013;2(6):105-8.

22. Murugan T, Wins JA, Murugan M. Antimicrobial activity and phytochemical constituents of leaf extracts of Cassia auriculata. Indian J Pharm Sci 2013;75(1):122-5. 